\title{
Invited review: Innovations and the future: where do new feeding developments fit within future hill country practices for sheep production?
}

\author{
S.A. McCOARD ${ }^{1}$, D. GINTER ${ }^{2}$ and P.R. KENYON ${ }^{3}$ \\ ${ }^{1}$ AgResearch Ltd, Grasslands Research Centre, Private Bag 11008, Palmerston North 4474, New Zealand \\ ${ }^{2}$ Animal Innovations, 6 Crompton Rd, Totness 5250, South Australia \\ ${ }^{3}$ Sheep Research Centre, Massey University, Private Bag 11222, Palmerston North, New Zealand
}

sue.mccoard@agresearch.co.nz

\begin{abstract}
New developments in the understanding of early life nutrition and whole of life performance offer opportunities for changing livestock performance in the future. How should hill country farmers use supplements and tactical nutritional additions to turn these insights into future benefits for sheep production? Opportunities may exist in adopting new forage species, and mixes of forage species, supplementary feeds and/ or functional supplements to enhance the performance of both the ewe and the lamb in late gestation and early lactation. The potential and problems of adding these as options into our pasture feeding system to more targeted feeding approaches are explored.
\end{abstract}

Keywords: sheep, nutrition, forage

\section{Key messages}

- Nutrition in early life can influence lifetime performance in sheep

- The interaction between genetics, nutrition, physiological state and the environment are drivers of performance

- Farmers should consider individual animal needs rather than flock averages.

\section{Current issues facing hill country farmers' ability to feed their livestock}

A pasture based system is efficient, sustainable and a low cost system that allows New Zealand to compete globally as a major exporter of food and fibre (Morris \& Kenyon 2014). Grazed pasture and forage crops supply in excess of $95 \%$ of the livestock diet on New Zealand farms (Hodgson et al. 2005), with the percentage likely higher on hill country where it is difficult to feed supplements due to topography. Of the total area farmed with sheep and beef cattle the annual rate of pasture renewal has been reported to be just $2.3 \%$ compared with $8 \%$ on dairy cattle farms, which are generally on easier and more fertile land (Stewart et al. 2014). This lower renewal rate is a result of a combination of costs associated with topography and profitability. Management options to improve sheep productivity on hill country through new forages need to keep this in mind.

Over the last 2 decades, sheep farming has gradually become more reliant on hill country landscapes which is often of lower fertility and subject to climatic extremes (Morris \& Kenyon 2015). This is because dairy farming has moved into many traditional lowland sheep farming areas (Mackay et al. 2011). While this has been occurring, performance of sheep farm systems have changed. Average lambing percentages (lambs weaned to ewes mated) have improved from approximately 100 to $128 \%$ with some farmers achieving greater than $180 \%$ through improved genetics, nutrition and animal husbandry. Furthermore, anecdotally, more lambs are being grown to slaughter weight on breeding units (i.e. finished) rather than sold to finishers, slaughter weights have increased and more ewe hoggets have been used for breeding on hill country during the last 2 decades (Ferguson et al. 2014; Morris \& Kenyon 2014). In the last 3 decades, productivity gains on sheep and beef farms in hill country have delivered eco-efficiency gains including $47 \%$ more saleable product per hectare, $21 \%$ reduction in nitrate leaching per $\mathrm{kg}$ of saleable product and $40 \%$ reduction in greenhouse gas emissions per $\mathrm{kg}$ of saleable product, along with increased meat production (Mackay et al. 2011). With farmers in many regions now operating in environments where there are limits on nutrient use, when considering feed resources, it is important to not only consider production efficiency gains in regards to production per hectare and animal welfare, but also respect for the environment.

Improved meat production combined with increased stocking rates and lambing percentages (Mackay et al. 2011) has resulted in increased numbers of 'high feed demand' animals (priority classes) on farm at any one time. This puts pressure on the traditional grassbased system and current farming systems employed on-farm. For example, rather than lambs being sold to finishers at weaning and ewe replacements not being bred until 18 months of age, hill country farmers are trying to finish lambs for slaughter and grow hoggets for breeding during the summer/autumn when pasture growth and quality is variable (Hodgson \& Brookes 
1999; Matthews et al. 1999). The net effect of this is that mature ewes may not have access to suitable levels of herbage to regain condition post-weaning, while the following year's reproductive performance can be compromised, or pasture cover going into winter can be below target. The increasing difference between scanning and lambing percentage as fecundity increases (i.e. increased mortality as litter size increases), is speculated to be driven at least in part by insufficient feed allowance to multiple-bearing ewes. This is demonstrated by the increase in lambing percentage of triplet bearing ewes and thus lamb survival when feed allowance is increased resulting in increased lamb birth weight and viability (Everett-Hincks et al. 2005; Everett-Hincks \& Dodds 2008).

Greater pressure on hill country farming systems will further increase as farmers aim for additional levels of productivity through fewer, higher performing capital stock to remain profitable. The traditional pressure points of poor winter herbage production and the tendency of reduced pasture production and quality in summer/autumn will be exacerbated by increased per animal production levels. Future pasture-based systems will need to be more focused on individual animal demand, rather than feeding at the flock level, and breeding rather than finishing stock. The importance of meeting feed requirements and timing of optimal feeding levels will require more intensive management to provide the required accuracy in feed budgeting. In future, stocking rates may need to be reduced and additional feed brought into the system to meet performance targets. This creates another challenge as already over the last 3 decades sheep productivity per labour unit has improved by at least 35\% (Morris 2013).

\section{Challenges of meeting requirements of early life nutrition}

Sheep are often exposed to challenging nutritional environments in early life including multiple pregnancies (e.g. twins and triplets) where the foetuses compete for maternal nutritional resources in utero as well as during lactation, and hogget mating where there is competition for nutrients between the foetus and the growing dam. The consequences of reduced foetal growth are decreased survival, decreased post-natal growth, altered body composition, metabolic disorders and organ dysfunction (e.g. mammary gland, liver, small intestine and reproductive organs) (see reviews by Wu et al. 2006 and Kenyon \& Blair 2014).

The impact of ewe nutrition on foetal growth can be classified according to three developmental timeframes: the first trimester (day 0 to 45) when the embryo and placenta is established, the second trimester (day 45 to 90 ) when there is rapid growth of the placenta and foetal organs, and the third trimester (day 90 to 147) when rapid foetal growth occurs (Bell 1995). The third trimester is generally considered as the critical time point because the nutritional requirements of both dam and foetus increase markedly (Bell 1995). This is illustrated by the divergence in foetal growth observed between twins and singletons after $\sim 115$ days of pregnancy in well-fed dams as a consequence of placental insufficiency leading to a $15 \%$ difference in foetal weight by 140 days of pregnancy (McCoard et al. 2001). Restricted foetal nutrition in twins relative to singleton foetuses after 100 days of pregnancy is associated with reduced skeletal muscle weight as a result of placental insufficiency (McCoard et al. 1997; McCoard et al. 2000; Fahey et al. 2005). This is associated with reduced capacity for protein synthesis by the foetus (Greenwood et al. 2000; McCoard et al. 2001), lower postnatal growth, altered body composition and reduced lifetime performance (Barker 1998; Greenwood et al. 1998) including smaller and leaner carcasses at the same age relative to singletons (McCoard et al. 2010).

Limitations in pasture growth over winter, which coincides with mid-late pregnancy, can adversely affect ewe liveweight, ewe body condition and lamb birth weight (Kenyon \& Webby 2007; Kenyon et al. 2014). Nutritional requirement of ewes, especially with multiple foetuses, is high in late pregnancy and early lactation, with the critical period being the last 4-6 weeks before lambing (Scales et al. 1986). Tripletbearing ewes require a higher pasture allowance to reach similar production as twin-bearing ewes reaching similar litter survival compared to twins at a high pasture allowance $(2000 \mathrm{~kg} \mathrm{DM} / \mathrm{ha}$, Everett-Hincks et al. 2005). While meeting the nutritional requirements of ewes in mid-late gestation is important, optimal nutrition throughout the annual cycle is also key to improved production performance as indicated by the curvilinear relationship between BCS and productivity (Kenyon et al. 2014).

\section{Opportunities: nutritional intervention}

Herbage production and quality drives animal performance. In some hill country farming systems, use of additional feed sources such as crops and supplements is limited because of a combination of topography, climate and profitability. In the first instance, farmers need to utilise existing feed resource efficiently. Through the advent of ultrasound (pregnancy) scanning, farmers have the ability to feed ewes in late pregnancy based on the number of foetuses carried, thus targeting those with the greatest need, i.e. multiple-bearing ewes. Further, it is now well established that body condition score affects production (Kenyon et al. 2014) and that ewes of poorer condition are less able to cope with poor 
nutrition. Optimal ewe body condition score is in the range of 3.0 to 3.5 throughout pregnancy (Kenyon et al. 2014). Using this information, farmers can identify and target those individual ewes with low body condition scores who would benefit the most from additional feeding. This split flock approach based on 'need' of the individual rather than the flock has the additional advantage of being a more efficient use of feed, especially when supply is limited. Times when this approach might be used include late pregnancy, at setstocking and post-weaning before re-breeding (Kenyon et al. 2004; 2014).

Alternative use of forage: Sheep farmers with cultivatable land have traditionally utilised annual crops, such as brassicas, as a winter feed source for ewes under mob grazing and to finish lambs in summer/ autumn (Coop 1986). While these have traditionally been used on an easier class of land, farmers have developed systems such as 'spray and pray' to establish brassicas on steeper hill country. While there are anecdotal examples of success with this approach, farmers need to be careful with mob stocking ewes in winter not to cause erosion.

Monocultures of red and white clover, plantain and chicory have also been utilised, although these have limitations in terms of seasonal herbage production and longevity (Kemp et al. 2010). There has been recent interest in using permanent mixed herb/clover swards to reduce the impact of seasonal herbage production and improve herbage quality during the summer/autumn, resulting in increased animal performance (see reviews Kemp et al. 2011; Cranston et al. 2015). However, the majority of studies to date have tended to be undertaken on an easier class of land. Therefore, it is difficult to quantify their potential benefit under hill country farming conditions. Further research is required before clear conclusions can be drawn.

\section{Feed efficiency in grazing systems - innovations}

Farming profitability is profoundly dependent on the efficiency of animals to convert available feed into saleable product. Whilst genetics determines an animal's underlying potential for conversion of feed to meat, milk and/or wool, factors like health, developmental history, stage of production and nutrition govern the level to which that potential is ultimately expressed.

In nutrition, concentrations of energy (as metabolisable energy, MJME) and to a lesser extent protein (as crude protein), are frequently employed as indicators of an animal's potential weight gain and/ or milk output from a given feed. As a result, these measures have become the most commonly used industry benchmark for assessing relative feed quality. When applied to predicting feed conversion efficiency, however, the feed quality model is less reliable because, in practice, different feeds containing similar ME and protein concentrations often produce remarkably different feed efficiency outcomes. Pastures and fodder crops are particularly problematic in this respect. Thus, when using nutritional intervention to maximise feed efficiency in grazing systems, a much deeper understanding of the critical role dietary components other than ME and crude protein play in either directly or indirectly influencing an animal's capacity to express its true potential for meat, milk or wool production is required.

In ruminants, meeting the challenge to produce more saleable product from less feed means optimising the rumen microbial output of energy substrates (particularly volatile fatty acids) and protein precursors (amino acids). Simultaneously, the animals' physiological capacity to utilise these by-products needs to be maximised. Over recent years, advances in understanding of the role specific amino acids, minerals, trace elements, vitamins and carbohydrates play in potentiating both microbial growth and volatile fatty acid output, and improving the efficiency of cellular energy and protein synthesis, has considerably improved our capacity to meet these challenges.

Pastures and fodder crops provide variable supply of many of those nutrients, which are critical to maximising both rumen microbial and physiological efficiency in cattle and sheep. Therefore, the opportunity to use advanced nutritional complexes (i.e. combinations of specific nutrients such as vitamin and mineral mixes) to deliver improved productivity performance in grazing systems is important. Even with small dose rates (e.g. $20 \mathrm{~g} /$ head/day for sheep and $70 \mathrm{~g} /$ head/day for cattle, R. White \& E. Hicox unpublished observations) supplements of this kind are readily distributed to the stock using systems such as low cost, low labour inputweatherproof lick technology. For example, in a farmbased trial where cattle were grazed on a barley crop and provided access to weatherproof licks containing these technologies, animals showed markedly improved feed efficiency over 69 days, with weight gain increased by $10.23 \%$ with consumption of $20 \%$ less feed when compared with control groups (R. White \& E. Hicox unpublished observations). The potential benefits of such approaches in grazing systems have not been quantified but warrant further investigation.

Amino acid supplementation: Amino acids are not only used as a precursor for the synthesis of protein, glucose and other cellular metabolites, but there is a growing body of evidence that some amino acids have a role in regulating growth, reproduction and immunity through modulation of metabolic and cell signaling pathways. In sheep, there has been a particular focus on muscle growth, mammary gland development, 
immune function and foetal development and survival (McCoard et al. 2015). For example, maternal arginine supplementation can increase foetal growth, resulting in enhanced birth-weight of lambs from both underfed (Lassala et al. 2010) and well-fed ewes (Lassala et al. 2011, McCoard et al. 2013). Further, arginine supplementation to mid-late pregnancy ewes increases peri-renal fat stores (brown fat tissue that is critical for heat production) of lambs, as well as their corebody temperature at birth (McCoard et al. 2013; McCoard et al. 2014), which may have implications for survival. Maternal arginine supplementation can also improve muscle development and postnatal growth in female lambs (Sales 2014), and udder health and milk production in early lactation in the ewes (Sciascia 2014). These studies provide an example of the potential of amino acids (in this case arginine), administered during crucial phases of development, to influence key production performance traits in sheep. Our understanding of the potential for specific nutrients to alter production traits is in its infancy. There is an opportunity for future research to development new knowledge about amino acid biochemistry and physiology to support the design of targeted nutritional interventions to help improve ovine production performance.

\section{Adoption: some practical implications}

Representing about $30 \%$ of total land area and $71 \%$ of pastoral land use in New Zealand, sheep and beef farming is a dominant component of our landscape, with hill country farming posing some unique challenges, but also some opportunities for farming into the future. Increasing the focus on managing individual reproductive animals based on their requirements through the full life cycle (conception to adulthood) rather than at the flock level, in addition to more targeted finishing of animals, offers potential to deliver performance gains, including reducing chemical and drug inputs. To achieve this outcome, adoption of new and existing technologies to monitor individual animal performance (e.g. EID technology) and new forages/crops/feed supplements, including practical methods of planting/establishing alternative herbages on hills and/or feeding out concentrates/supplements and associated feeding management protocols to minimise health issues, are required. Maximising returns from such approaches needs to be evaluated at the whole farm level to ensure that changes made in one component of the system (e.g. increased fecundity) is matched by appropriate changes in the farming system to realise those gains (e.g. stocking rate and grazing management). Other aspects of the farming system, including other input costs such as fertiliser use, environmental impact from contaminant load entering waterways (nutrients including nitrogen and phosphate, sediment and faecal microbes) and greenhouse gases, animal health and labour requirements, and lifestyle choices also need to be considered when changing farming intensity (extensive versus intensive) and/or adoption of new technologies. Improving profitability of sheep flocks in hill country requires future basic and applied research in these key areas to meet the goal of sustainable and profitable farming.

\section{ACKNOWLEDGEMENTS}

The authors thank Drs Alec Mackay, Ian Sutherland and Ajmal Khan for their critical review of this manuscript.

\section{REFERENCES}

Barker, D.J. 1998. In utero programming of chronic disease. Clinical Science 95: 115-128.

Bell, A.W. 1995. Regulation of organic nutrient metabolism during transition from late pregnancy to early lactation. Journal of Animal Science 73: 28042819.

Cranston, L.M.; Kenyon, P.R.; Morris, S.T.; Kemp, P.D. 2015. A review of the use of chicory, plantain, red clover and white clover in a sward mix for increased sheep and beef production. Proceedings of the New Zealand Grasslands Association 77: 89-94.

Coop, I.E. 1986. Pasture and crop production. pp. 110136. In: Sheep production (Vol. 2), Feeding, growth and health. Eds. McCutcheon, S.N.; McDonald, M.F.; Wickham, G.A. New Zealand Institute of Agricultural Sciences.

Everett-Hincks, J.; Blair, H.; Stafford, K.; LopezVillalobos, N.; Kenyon, P.; Morris, S. 2005. The effect of pasture allowance fed to twin-and tripletbearing ewes in late pregnancy on ewe and lamb behaviour and performance to weaning. Livestock Production Science 97: 253-266.

Everett-Hincks, J.; Dodds, K. 2008. Management of maternal-offspring behavior to improve lamb survival in easy care sheep systems. Journal of Animal Science 86: E259-E270.

Fahey, A.; Brameld, J.; Parr, T.; Buttery, P. 2005. The effect of maternal undernutrition before muscle differentiation on the muscle fiber development of the newborn lamb. Journal of Animal Science 83: 2564-2571.

Ferguson, D.M.; Schreurs, N.M.; Kenyon, P.R.; Jacob, R.H. 2014. Balancing consumer and societal requirements for sheep meat production: An Australasian perspective. Meat Science 98: 477-483.

Greenwood, P.L.; Hunt, A.S.; Hermanson, J.W.; Bell, A.W. 1998. Effects of birth weight and postnatal nutrition on neonatal sheep: I. Body growth and composition, and some aspects of energetic efficiency. Journal of Animal Science 76: 2354-2367. 
Greenwood, P.L.; Slepetis, R.M.; Bell, A.W. 2000. Influences on fetal and placental weights during mid to late gestation in prolific ewes well nourished throughout pregnancy. Reproduction, Fertility and Development 12: 149-156.

Hodgson, J.; Brookes, I.M. 1999. Nutrition of grazing animals. pp. 117-132. In: New Zealand pasture and crop science. Eds. White, J.G.H.; Hodgson, J. Oxford Press.

Hodgson, J.; Cameron, K.; Clark, D.; Condron, L.; Fraser, T.; Hedley, M.; Holmes, C.; Kemp, P.; Lucas, R.; Moot, D.; Morris, S.; Nicholas, P.; Shadbolt, N.; Sheath, G.; Valentine, I.; Waghorn, G.; Woodfield, D. 2005. New Zealand's pastoral industries: Efficient use of grassland resources. pp. 181-205. In: Grasslands, Developments, opportunities, perspectives Eds. Reynolds, S.G.; Frame, J. New Hampshire, USA: Science Publication.

Kemp, P.D.; Kenyon, P.R.; Morris, S.T. 2010. The use of legume and herb forage species to create high performance pastures for sheep and cattle grazing systems. Revista. Brasileira Zootecnia 39: 169-174.

Kenyon, P.R.; Morel, P.C.; Morris, S.T. 2004. The effect of individual liveweight and condition scores of ewes at mating on reproductive and scanning performance. New Zealand Veterinary Journal 52: 230-235.

Kenyon, P.R.; Webby, R.W. 2007. Nutritional management of sheep. pp. 255-274. In: Pasture and supplements for grazing animals. Eds. Rattray, P.V.; Brookes, I.M.; Nicol, A.M. New Zealand Society of Animal Production, Occasional Publication 14.

Kenyon, P.R.; Blair, H.T. 2014. Foetal programming in sheep - Effects on production. Small Ruminant Research 118: 16-30.

Kenyon, P.; Maloney, S.; Blache, D. 2014. Review of sheep body condition score in relation to production characteristics. New Zealand Journal of Agricultural Research 57: 38-64.

Lassala, A.; Bazer, F.W.; Cudd, T.A.; Datta, S.; Keisler, D.H.; Satterfield, M.C.; Spencer, T.E.; Wu, G. 2010. Parenteral administration of 1-arginine prevents fetal growth restriction in undernourished ewes. Journal of Nutrition 140: 1242-1248.

Lassala, A.; Bazer, F.W.; Cudd, T.A.; Datta, S.; Keisler, D.H.; Satterfield, M.C.; Spencer, T.E.; Wu, G. 2011. Parenteral administration of L-arginine enhances fetal survival and growth in sheep carrying multiple fetuses. Journal of Nutrition 141: 849-855.

Mackay, A.D.; Rhodes, A.R.; Power, I.; Wedderburn, M.E. 2011. Has eco-efficiency of sheep and beef farms changed in the last 20 years? Proceedings of the New Zealand Grasslands Association 73: 119124.

Matthews, P.N.P.; Hodgson, J.; White, J.G.H. 1999. Livestock farming systems in New Zealand. pp. 133-
152. In: New Zealand pasture and crop science. Eds. White, J.G.H.; Hodgson, J. Oxford Press.

McCoard, S.A.; Peterson, S.W.; McNabb, W.C.; Harris, P.M.; McCutcheon, S.N. 1997. Maternal constraint influences muscle fibre development in fetal lambs. Reproduction, Fertility and Development 9: 675681.

McCoard, S.; McNabb, W.; Peterson, S.; McCutcheon, S.; Harris, P. 2000. Muscle growth, cell number, type and morphometry in single and twin fetal lambs during mid to late gestation. Reproduction, Fertility and Development 12: 319-327.

McCoard, S.A.; McNabb, W.C.; Birtles, M.J.; Harris, P.M.; McCutcheon, S.N.; Peterson, S.W. 2001. Immunohistochemical detection of myogenic cells in muscles of fetal and neonatal lambs. Cells Tissues Organs 169: 21-33.

McCoard S.; Koolaard, J.; Charteris, A.; Luo D. 2010. Brief communication: Effect of twinning and sex on carcass weight and composition in lambs. Proceedings of the New Zealand Society of Animal Production 70: 133-136.

McCoard, S.; Sales, F.; Wards, N.; Sciascia, Q.; Oliver, M.; Koolaard, J.; van der Linden, D. 2013. Parenteral administration of twin-bearing ewes with L-arginine enhances the birth weight and brown fat stores in sheep. SpringerPlus 2: 684. http://dx.doi. org/10.1186/2193-1801-2-684

McCoard, S.; Wards, N.; Koolaard, J.; Salerno, M.S. 2014. The effect of maternal arginine supplementation on the development of the thermogenic program in the ovine fetus. Animal Production Science 54: $1843-$ 1847.

McCoard, S.A.; Sales, F.A.; Sciascia, Q.L. 2015. Invited review: Amino acids in sheep production. Frontiers in Bioscience 1: 264-288.

Morris, S.T. 2013. Sheep and beef cattle production systems. pp. 79-84. In: Ecosystems services in New Zealand. Ed. Dymond, J.R. Manaaki Whenua Press, Lincoln, New Zealand.

Morris, S.T.; Kenyon, P.R. 2014. Intensive sheep and beef production from pasture - A New Zealand perspective of concerns, opportunities and challenges. Meat Science 98: 330-335.

Sales, F. 2014. Amino acids and skeletal muscle growth in lambs. $\mathrm{PhD}$ thesis, Massey University, New Zealand.

Scales, G.H.; Burton, R.N.; Moss, R.A. 1986. Lamb mortality, birth weight and nutrition in late pregnancy. New Zealand Journal of Agricultural Research 29: 75-82.

Sciascia, Q.L. 2013. Mammalian target of rapamycin (mTOR) activation during ruminant mammary development and function. PhD thesis, Massey University, New Zealand. 
Stewart, A.; Kerr, G.; Lissaman, W.; Rowarth, J. 2014. Pasture and forage plants for New Zealand. Grassland Research and Practice Series (4th ed.). Dunedin, New Zealand: New Zealand Grassland Association.

Waghorn, G.; Woodfield, D. 2005. New Zealand's pastoral industries: Efficient use of grassland resources. pp. 181-205. In: Grasslands, developments, opportunities, perspectives. Eds. Reynolds, S.G.; Frame, J. New Hampshire, USA: Science Publication.

Wu, G.; Bazer, F.W.; Wallace, J.M.; Spencer, T.E. 2006. Board-invited review: intrauterine growth retardation: implications for the animal sciences. Journal of Animal Science 84: 2316-2337. 